Kazimierz Oźóg ๑

Uniwersytet Rzeszowski, Rzeszów

prof.ozog@gazeta.pl

\title{
PEJZAŻ SEMIOTYCZNY PROFESORA BOGUSŁAWA DUNAJA
}

Mam zaszczyt należeć do uczniów Pana Profesora, który po nieoczekiwanej, nagłej śmierci Profesora Mieczysława Karasia w roku 1977 stał się moim przełożonym. Najpierw pod Jego kierunkiem obroniłem w roku 1982 doktorat, potem czuwał nad moją habilitacją, obronioną w roku 1991, a od roku 2003 wchodzę w skład szóstki profesorów tytularnych, „wypuszczonych w świat” przez naszego Mistrza. Z okazji Jego wspaniałego Jubileuszu: 80 . urodzin i 50 -lecia obrony pracy doktorskiej, poproszono mnie, abym napisał niewielki tekst przybliżający tę znamienitą Osobę. Trudne zadanie postawił przede mną profesor Maciej Rak, redaktor naczelny „LingVariów”. Zdaję sobie sprawę, że będzie to tylko szkic do portretu, bo słowa są za małe, aby objąć i scharakteryzować Profesora, a dodatkowo tekst, według wymogów redakcyjnych, musi być krótki. Mogę zatem dać tylko zarys Postaci, będzie to szkic napisany według podstawowej w języku metafory życie to droga. Chcę wykonać swoisty pejzaż semiotyczny drogi życiowej Profesora Bogusława Dunaja, bo wszystko, co nas otacza, jest dzisiaj nasemantyzowane. Wybrałem spośród wielu tylko kilka przystanków w tej drodze, można je nazwać słowami kluczami Jego życia.

Przystanek Kraków - to najważniejszy przystanek naszego Mistrza, przystanek tak wielki, że stał się bazą na całe dorosłe życie. Bogusław Dunaj przyjechał do Krakowa w roku 1958 z drugiego końca Polski, z północnych Ziem Odzyskanych, które wtedy świeżo po wojnie z trudem się integrowały z Macierzą. Przywiózł doświadczenia z przystanku nowogródzkiego i malborskiego. Kraków stał się Jego przeznaczeniem. Każde miejsce tego miasta to znaczący element pejzażu semiotycznego Profesora: Uniwersytet Jagielloński, polonistyka na Gołębiej, Katedra Historii Języka i Dialektologii WP UJ, Biblioteka Jagiellońska, ulica Sławkowska, Rynek Główny, plac 
$\mathrm{Na}$ Groblach, Aleje, krakowskie instytucje naukowe, muzea, krakowskie kościoły. Ogromne uniwersum współczesne, historyczne i kulturowe, a w nim Profesor Dunaj.

Przystanek praca naukowa. Bogusław Dunaj może stanowić prototyp profesora. Jeśli przeprowadzilibyśmy badania ankietowe (dzisiaj bardzo modne) i zadalibyśmy pytanie: Jak wyobrażam sobie profesora wyższej uczelni?, to odpowiedzi byłyby zupełnie zgodne z tym, co reprezentuje Profesor Dunaj: pracowity, inteligentny, opanowany, zrównoważony, kreatywny, o ogromnej wiedzy, wymagający najpierw od siebie, a potem dopiero od innych, pasjonat, znakomicie mówiący, empatyczny, łatwo nawiązujący kontakt z otoczeniem, z poczuciem humoru, elegancki.

Jako przedmiot swoich badań językowych wybrał Profesor język polski i związaną z nim naszą ojczystą kulturę. To ważny z kilku względów obszar badanej rzeczywistości; język stanowi bowiem najdoskonalszy system znaków funkcjonujących wśród ludzi. Jest ważny dla osoby, grupy, narodu, stanowi fundament każdej kultury, a praca nad językiem to praca nad człowiekiem. Profesor Dunaj należy do tych wielkich badaczy języka polskiego, którzy z prawdziwą swobodą, można rzec z niezwykłą wolnością twórczą, przybliżają różne obszary badawcze w zawrotnie dziś postępującej w nauce specjalizacji wąskich dyscyplin. Językoznawstwo w wydaniu Bogusława Dunaja to lingwistyka szeroka, ciągle otwarta, ale bardzo precyzyjna, pilnująca odrębności, z wielkim sukcesem łącząca badania historii języka, znakomite studia nad polszczyzną współczesną, obserwacje języka mówionego i polskich gwar. Profesor Dunaj w swojej pełni naukowej jest wybitnym historykiem języka polskiego, niedościgłym badaczem polszczyzny współczesnej, wreszcie uznanym dialektologiem. Każda Jego książka, powstanie każdego prowadzonego przez Niego zespołu, wydawane pod Jego kierunkiem tomy zbiorowe to liczące się zdarzenia naukowe w polskim językoznawstwie. Wprowadzane przez Niego w trzech ostatnich dekadach XX wieku nowatorskie, twórcze ujęcia metodologiczne stanowiły przełom, wytyczały nowe kierunki i sposoby naukowych dociekań, by przytoczyć tylko badania języka mówionego na przykładzie mieszkańców Krakowa i Nowej Huty czy wydawany wielokrotnie Słownik współczesnego języka polskiego. Jeśli chodzi o badania prowadzone przez nas, Jego uczniów, to był równorzędnym partnerem w dyskusjach, nie dawał odczuć swej wyższości, uważnie słuchał naszych koncepcji, pozwalał na szerokie, interdyscyplinarne ujęcia, jak w moim przypadku w rozprawie o zwrotach grzecznościowych pozwolił na stworzenie szerokiego modelu grzeczności i na włączenie obserwacji z psychologii społecznej.

Pracując z nami w różnych zespołach, przekazywał nam precyzyjne reguły naukowej gry, a przy analizie wielu materiałów, zwłaszcza nagrań języka mówionego i dokumentacji gwarowej, był aż do bólu perfekcyjny, dokładny, próbował wyjaśnić każdą wątpliwość. Dla Niego podstawą wszystkich obserwacji językowych powinien być obszerny materiał. Jest przeciwnikiem jałowego teoretyzowania niepopartego twardymi faktami. To przeświadczenie, charakterystyczne dla lingwistycznej szkoły krakowskiej, przejął od swoich mistrzów i przekazał je nam. 
Przystanek praca dydaktyczna. Miałem szczęście najpierw jako student uczestniczyć w zajęciach prowadzonych na Uniwersytecie Jagiellońskim przez Bogusława Dunaja i kolejno, jako młody pracownik naukowy, asystent i adiunkt, podlegać Jego dydaktycznemu oddziaływaniu. Zdawałem u Niego kolokwia, egzaminy, uzyskiwałem zaliczenia, uczestniczyłem w prowadzonych wykładach i ćwiczeniach. Od razu można było zauważyć, że Profesor jednakową wagę przywiązuje do pracy naukowej i dydaktycznej. Traktował studentów poważnie, jak partnerów, nie tylko uczył trudnych kwestii merytorycznych (gramatycznych i kulturowych) podczas świetnie przygotowanych za każdym razem zajęć, ale dawał odniesienia do spraw ogólniejszych, życiowych, był znakomitym wychowawcą. Pamiętamy do dziś Jego krótkie, dowcipne komentarze do różnych życiowych sytuacji. Obowiązkowy, punktualny, słowny, wiele od studentów wymagał, był bardzo sprawiedliwy w ocenach i niezłośliwy. Nie znosił jednak lenistwa i krętactwa, że „coś tam się powie”. Mówił: „W gramatyce nie ma "coś«, w gramatyce są konkrety i trzeba je poznać". Żartowaliśmy nawet, że Dunaj jest przykładem „praktycznego” strukturalizmu; dla Niego rzeczy ogromnie ważne w życiu to organizacja, porządek, precyzyjnie wydzielone opozycje, przyporządkowania, funkcje, zhierarchizowanie spraw - tak jak w strukturalizmie. Niektórzy koledzy, przyzwyczajeni do literackiej awangardy, po prostu zmieniali grupę. „Przepłynąć Dunaj” na egzaminie z scs., z gramatyki opisowej języka polskiego, a zwłaszcza z gramatyki historycznej to były dla wielu wyczyny na miarę ukończenia studiów - powód do wielkiego świętowania w Żaczku czy w Nawojce.

Przystanek góry, zwłaszcza Beskidy. Jest to wspaniały składnik pejzażu semiotycznego Profesora Bogusława Dunaja. Wychowany na Pojezierzu Mazurskim, często odwiedzający z powodów rodzinnych Gdańsk (a więc morze), pokochał góry. Tę fascynację górami przekazał nam, swoim studentom i uczniom. Dunaj to niezmordowany turysta, pełen pasji poznawania świata, szczególnie Polski południowej. Jako znakomity wychowawca doskonale wiedział, że chwile spędzone w górach z uczniami na niespiesznych wędrówkach czy obozach dialektologicznych są cenne z wielu powodów, zarówno poznawczych, jak i wychowawczych. W czasie obozów dialektologicznych wykonaliśmy dokumentację gwarową i kulturową od Beskidu Śląskiego aż po Beskid Niski. Widoki z beskidzkich szczytów zapierały dech w piersiach, a Profesor za każdym razem umiał to wykorzystać naukowo i wychowawczo, także patriotycznie. Pamiętam widoki na Tatry z Babiej Góry, Lubonia Wielkiego, Dzwonkówki, Turbacza, Radziejowej... i uśmiechniętego Profesora. „Kazimierzu, jest dobrze” - mówił. „Jest bardzo dobrze” - odpowiadałem.

Przystanek radość tworzenia. Rzadko wśród uczonych można spotkać osobę, która $\mathrm{z}$ taką radością, $\mathrm{z}$ taką wewnętrzną pogodą i wolnością oddawałaby się pracy naukowej. Profesora Dunaja pociąga niezmiennie od lat poznawanie świata, ludzi i wielkich obszarów języka i kultury. To realizacja Jego powołania, jest przecież znakomitym Profesorem. Skąd zatem radość? Radość jest zawsze naszą odpowiedzią na jakieś dobro, które realizujemy bądź którego doświadczamy. Profesor wie, że praca 
dydaktyczna i praca naukowa to wielkie znaki aksjologiczne, to dobro przekazywane drugiemu człowiekowi i wspólnocie, także Polsce. To dobro jest siłą napędową Jego twórczości i właśnie to dobro przynosi Mu radość. Niech ta radość trwa jak najdłużej. Niech Twoje święto trwa bez końca!

Przystanek Warszawa. Warszawa chciałaby przyciągnąć Profesora do siebie, ale On świadomie wybrał Kraków. Jednak przez całe naukowe życie jeździ do Warszawy na zebrania naukowe, na obrony doktoratów, habilitacje, posiedzenia Rady Języka Polskiego, Komitetu Językoznawstwa PAN. I wraca do umiłowanego Krakowa. A na południu są góry.

Przystanek dzieło otwarte. To ważny, aktualny składnik pejzażu semiotycznego Profesora Dunaja. Rozpoczęte przez Niego dzieła, analizujące współczesny system gramatyczny języka polskiego i różne zmiany tego systemu na tle zmian kulturowych, zapowiadają się znakomicie. Profesor niezmordowanie pracuje nad ich ukończeniem. Życzymy, aby nasz Mistrz ukończył je i rozpoczął nowe dzieła otwarte, traktujące o języku człowieka i wspólnoty.

Panie Profesorze! Życzymy zdrowia i ciągłego przekazywania nam wspaniałych owoców Pańskiej pracy! 